\title{
A Spatial Dynamic Model for Export Intensity of Hazardous Industrial Waste: The Incentive Effect of Regional Environmental Policies
}

\author{
Jaime Vallés-Giménez ${ }^{1,3}$ (D) A Anabel Zárate-Marco ${ }^{2,3}$ (D)
}

Accepted: 2 October 2021 / Published online: 18 October 2021

(c) The Author(s) 2021

\begin{abstract}
This paper analyses, in the context of the Environmental Kuznet Curve, the determinants of export intensity of hazardous industrial waste among Spanish regions, with particular attention to the influence of waste taxes and of environmental policies. This study is carried out for the first time in the literature with a spatial dynamic model, fixed effects and panel data for the 17 regions (Comunidades Autónomas) of Spain during the period 2007-2017. The results suggest there is a spatial-dynamic component to export intensity, and that both regional taxes on waste disposal and environmental policy stringency appear to encourage, albeit modestly, the rate of exported waste to other regions. The model also shows that the more regions recycle, and the greater the economies of scale arising from industrial agglomeration, the lower is the region's waste export intensity, although increasing restrictions on the international trade in hazardous waste have intensified trading inside the country. Finally, the results suggest a non-linear relationship between growth and export intensity, although apparently we are still far from the absolute decoupling of the Environmental Kuznet Curve.
\end{abstract}

Keywords Hazardous industrial waste $\cdot$ Export intensity $\cdot$ Waste disposal tax · Environmental policy stringency $\cdot$ Spatial nexus $\cdot$ Temporal persistence

JEL Classification F1 $\cdot \mathrm{H} 2 \cdot \mathrm{H} 3 \cdot \mathrm{H} 7 \cdot \mathrm{Q} 5$

Anabel Zárate-Marco

azarate@unizar.es

Jaime Vallés-Giménez

jvalles@unizar.es

1 Department of Applied Economics, Faculty of Economic and Business, University of Zaragoza,

Granvía 2, 50005 Zaragoza, Spain

2 Department of Applied Economics, Faculty of Economic and Business (Edificio Lorenzo Normante), University of Zaragoza, María de Luna s/n, 50018 Zaragoza, Spain

3 IEDIS, University of Zaragoza, Zaragoza, Spain 


\section{Introduction}

The pace and volume of industrial waste generation have created a trade flow of waste on an international scale, involving both European countries which sell part of their waste to each other, to be treated, recycled, and in the best-case scenario, its value recovered; and developing countries, which sometimes become the main importers of the industrial waste of rich countries. However, most of the trade in hazardous waste takes place within national borders, so that as Jensen (2012) argues, examining subnational hazardous waste flows is more informative than international flows for modellers and political leaders.

The environmental standards and taxes established in different economies may, among other effects, disincentivise waste generation, or favour its recycling (Sigman 1996; Sasao 2014b); incentivise illegal dumping (D’Amato et al. 2014; Sasao 2014c); stimulate a shift of polluting industries to other jurisdictions (Cole et al. 2010; Dou and Han 2019); and even affect waste trade flows. This final point will be the subject of this paper, in which we will analyse, in the context of the Environmental Kuznets Curve (EKC), the influence of environmental policies and taxes on the decision of industries to leave generated waste in the region or export it to other regions, for which we analyse the export intensity of hazardous industrial waste at the subnational level. Empirical evidence on waste flows is scanty, both at the international and at the subnational level, and the few studies that exist lack a series of elements which appear to be fundamental for its analysis, as we will see below, indicating that this paper is useful and timely.

The few studies analysing the influence of environmental regulation and/or taxation on the international flow of industrial waste have contradictory results. Fikru (2012) finds evidence that the European Union countries most likely to export hazardous waste are those where waste is most heavily regulated and taxed, and where environmental tax revenue has the most weight. However, Amouzou and Boudier (2016) find that for the hazardous waste trade in the EU, countries with strict environmental regulations do not export their waste to countries with laxer regulations, but to countries with a high waste treatment capacity. The recent contribution of Glover (2017), using partial least squares-structural equation modelling (PLS-SEM) to analyse the determinants of importing (electronic) waste from 130 countries, suggests that environmental regulations reduce waste imports only slightly.

Other papers which could also be useful for explaining international flows of industrial waste, even if they do not explicitly include taxes or regulation, but economic development indicators, are those using gravity models. ${ }^{1}$ With a gravity model and using a two-stage regression analysis and per capita income as a proxy for regulatory costs, Baggs (2009) analyses the movements of hazardous waste between OECD and non-OECD countries, finding that high-income countries import less waste, although understanding that this effect might be better explained by differences in capital per worker than per capita income. With a sample of hazardous and non-hazardous waste for 92 countries, Kellenberg (2012) also provides evidence that waste imports increase in countries whose environmental regulations are becoming looser than those of their trading partners. However, Higashida and Managi (2014) and Nuñez-Rocha (2016) find no evidence for a pollution haven for waste.

At the subnational level, the empirical evidence is also very scanty, although it gives more homogeneous results. Reams et al. (1993) and Levinson (1999a, b) find clear

\footnotetext{
1 According to Glover (2017), gravity models can report whether a waste haven effect is appearing, but do not generally corroborate which variables have the most effect on waste flows.
} 
evidence that hazardous waste imports in Louisiana and in the United States, respectively, are highly tax-sensitive. Along the same line, Alberini and Bartholomew (1999) for California identify the cost of waste disposal at the destination as an explanatory factor for the destination of a certain hazardous waste (halogenated solvents), and Levinson (2000), as well as obtaining similar results on imports, finds evidence that waste taxes in the United States incentivises waste exports. Sasao (2014c and d) also finds that taxes on industrial waste applied in Japanese prefectures have reduced the trade in industrial waste. And although it does not consider the effect of environmental taxes, the paper by Jensen (2012) for the United Kingdom is especially interesting, as it warns of the need to use spatial econometric models to explain the flow of industrial waste, in order to take into account possible spatial dependence problems. However, Jensen (2012) does not find evidence that spatial dependence parameters are significant.

Meanwhile the fact that the implementation of environmental regulations and taxes is often decentralised calls into question their effectiveness, due to the possible existence of tax competition or imitation processes. This has also led to the development of a parallel literature analysing competition between jurisdictions regarding environmental taxes and regulations (e.g. Levinson 2003; Kunce and Shogren 2005). However, much of this literature does not find evidence of a race to the bottom in environmental tax, and there are even papers showing the opposite effect (e.g. Millimet 2003). In fact, cooperation on environmental matters has become a key element of pollution management and control, given its strongly spatial nature, as the environmental damage control has the externality characteristics of a public good, creating a problem of spatial association ( $\mathrm{Su}$ and $\mathrm{Yu} 2019)$. Several papers have demonstrated the need to control the spatial dimension of the environmental problem, both in urban waste (e.g. Mazzanti et al. 2012) and in environmental pollution (e.g. Xiong et al. 2018), to avoid skewed and inconsistent results (Anselin 1988). As far as we know, in the field of inter-jurisdictional hazardous waste flows, Jensen (2012) has been the only paper to consider that the traditional inclusion in gravity models of variables linked to distance, transport costs or neighbourhood does not solve the spatial dependence problems, as regions are not spatially independent; so spatial econometric models are needed to take into account the spatial dependence underlying waste trade flows.

The literature also shows the need to take a dynamic approach to environmental topics, given that the behaviour of polluting agents tends to persist over time, as demonstrated by Sasao (2014a) on waste, and Zhang et al. (2017) on emissions. Also in the context of industrial waste flows, we can expect dynamic behaviour, given that the availability of treatment plants and the technology required to introduce value recovery processes demand considerable investment effort, and this usually also takes time. However, the available evidence to date has not taken this fact into account.

After reviewing the existing literature, we can conclude that there are hardly any empirical studies of the consequences that decentralising environmental taxation may have on industrial waste exports, and the few that exist take a static approach, without considering spatial dependence problems. Ignoring these matters could give incorrect, skewed results, meaning that any measures taken would be unsuitable and thus not at all effective, as part of the effect corresponding to these spatial dependence and temporal persistence factors would be wrongly attributed to other variables in the model. Also, if the existence of a spatial relationship in industrial waste exports is demonstrated, the regions should adopt any economic policy measures arising from the study in a coordinated manner (in order to internalise these spillover effects), rather than each administrative unit acting independently. For this reason, this paper takes into account the possibility of spatial nexus between regions and temporal persistence in waste exports. Moreover, our paper focuses on 
industrial waste exports at the regional level, an area in which published work is scarce but waste flows are larger, ${ }^{2}$ especially since the introduction of new international restrictions on international trade in waste and European regulations requiring waste to be managed as near as possible to where it is generated. Specifically, we use the taxation experience of the 17 Spanish regions from 2007 to 2017, the period for which hazardous waste export figures were available. We think this analysis scenario is appropriate, given the lack of studies in Spain on this subject, and it also suits our purposes, as all the regions apply environmental regulations and laws, and 9 of them have established a waste disposal tax, providing an almost equal sample of regions with and without waste disposal tax. Hence, there may be lessons to be learned from the example of Spain.

Thus, this paper covers a gap in the literature, as it analyses for the first time whether the environmental regulations and waste disposal taxes established in Spain at the regional level incentivise the export intensity of hazardous industrial waste, while controlling the dynamic nature of these waste flows and the spatial nexus between regions, again for the first time in the comparative literature; therefore, it represents a step forward in the methodology used to date for analysing waste flows. It also tests other hypotheses which we have considered could be relevant in the explanation of export intensity, such as international restrictions on transporting hazardous waste, increased recycling and value recovery, the income, and the existence of the waste haven effect. To do this, we use a Kuznets curve type function, including region and time fixed effects. The results obtained suggest that there is spatial interaction and dynamic behaviour in regional export intensity of hazardous industrial waste; also, a non-linear relationship between growth and export intensity, although apparently we are still far from the absolute decoupling of the Environmental Kuznets Curve; and that the waste disposal taxes and environmental policy stringency of Spanish regions do indeed favour, to some extent, the intensity of exports of this waste to other regions.

The paper is organised as follows: The second section discusses the model used and the hypotheses to be tested. The third section presents the results obtained. We conclude with some final considerations.

\section{A Model to Explain Export Intensity of Hazardous Industrial Waste Between Regions}

The theoretical model or hypothesis underlying our estimation relates economic growth and the environment through the EKC. ${ }^{3}$ This hypothesis establishes that the relation between environmental degradation and per capita income follows an inverted U-shaped path, with the explanation that the initial stage of growth (when clean, efficient technology is not available) brings a deterioration of environmental quality, associated with the scale effect which directly relates production and contamination. After this first phase, there is a turning point where the environmental degradation stops and begins to be reversed, while per capita income continues rising thanks to the new production techniques and the changes to the productive structure that come with economic growth, favouring activities that are less

\footnotetext{
${ }^{2}$ For example, in 2007, 97\% of all hazardous waste transported in the United Kingdom remained in the country, a surprisingly similar percentage to hazardous waste transfers in the United States (Jensen 2012).

3 See, for example, Stern et al. (1996), Bruyn et al. (1998), Dinda (2004), Özcan and Öztürk (2019), (2019), and Sarkodie and Strezor (2019).
} 
harmful to the environment (Grossman and Krueger 1995). Meanwhile, we must take into account that, insofar as environmental quality can be considered a normal good (demand for which increases with income), economic growth usually involves a change in the structure of preferences of demand, in favour of goods or behaviours which have a lower impact on the environment, and a growing pressure demanding stricter environmental regulations (Dinda 2005).

For these reasons, the EKC, as it is usually modelled, can be considered a minimised expression of a function which can really capture other hypotheses, as well as income, such as changes in the composition of national production favouring the environment, new technologies, the pressures associated with more information and education about environmental consequences, or public policies focusing on conserving natural resources (Selden and Song 1994; Grossman and Krueger 1995; Bruyn 1997; Ekins 1997; McConnell 1997; or Rothman and Bruyn 1998).

It is in this context that this paper explains industry behaviour, estimating a Kuznets curve-type function for the export intensity of hazardous waste from the region. ${ }^{4} \mathrm{We}$ do so for a sample comprising the 17 regions of Spain, using a dynamic spatial model for the period 2007-2017. The introduction of the dynamic component allows us to see whether the export behaviour of the regions today depends on past behaviour. And we will consider spatial dependence as broadly as possible, taking into account the possibility that a region's export intensity may depend on the past and present intensity export of the other regions; on certain factors explaining the exports of neighbouring regions, such as their environmental taxes and regulations; and on possible omitted variables which could also be spatially correlated. To do this, the general specification of the model used will be as follows:

$$
\begin{gathered}
H W E_{i t}=\delta \sum_{j \neq i}^{N} \omega_{i j} H W E_{j t}+\lambda \sum_{j \neq i}^{N} \omega_{(i j) t-1} H W E_{j t-1}+\mu H W E_{i t-1}+\sum_{w=1}^{W} y_{i t w} \beta_{w} \\
+\sum_{v=1}^{V} \sum_{j \neq i}^{N} \omega_{i j} z_{j t v} \alpha_{v}+\phi_{i}+\tau_{t}+u_{i t} \\
u_{i t}=\sigma \sum_{j \neq i}^{N} \omega_{i j} u_{i t}+\varepsilon_{i t}
\end{gathered}
$$

where $H W E_{i t}$ measures the tonnes of hazardous industrial waste that region $i(i=1, \ldots, 17)$ exports to other Spanish regions, as a percentage of the tonnes of hazardous industrial waste generated by that region $i$ in the year $t(t=1999, \ldots, 2017)$. As the Spanish Ministry for Ecological Transition and the Demographic Challenge ${ }^{5}$ indicates, the definition of hazardous industrial waste in Spain is as established in EU regulations. Thus, hazardous waste is any substance listed in Commission Decision 2000/532/CE, later amended by Decision 2014/955/EU; or which presents any of the hazardous properties listed in Appendix of Directive 2008/98/EC, amended by EU Regulation 1357/2014, and transposed as Spanish Law 22/2011 (irritant, carcinogenic, harmful, etc.); or any waste thus classified by the government in accordance with EU regulations or the international agreements to which

\footnotetext{
${ }^{4}$ Fikru (2012) and Levinson (2000) also use export intensity as a dependent variable.

5 https://www.miteco.gob.es/es/calidad-y-evaluacion-ambiental/temas/prevencion-y-gestion-residuos/flujos/Residuos_con_caracteristicas_peligrosidad.aspx.
} 
Spain is a signatory; as well as any recipients or containers which may have contained such waste.

Meanwhile, the concept of hazardous waste exports we use is established in international legislation ( Kiev protocol and Aarhus Convention) and European regulations (Regulation of the European Pollutants Release and Transfer Register, E-PRTR), and has been introduced into Spanish law through Real Decreto 508/2007, and subsequent amendments. Specifically, we obtained the data on hazardous waste exported to other regions (numerator of our dependent variable HWE) from the Spanish section of the E-PRTR, the Registro Estatal de Emisiones y Fuentes Contaminantes ${ }^{6}$ (State Pollutant Release and Transfer Register, hereafter PRTR-España) published by the Spanish Ministry for Ecological Transition and the Demographic Challenge, designed to apply at the community level the CEPE/ONU PRTR Protocol, which was signed by the European Community and 23 additional States in 2003. ${ }^{7}$ In accordance with Article 5 of the E-PRTR Regulation, this Register shows the amounts of waste exported by each facility engaged in one or more industrial activity (of those specified in Appendix of the E-PRTR Regulation), and which exceed the threshold of 2 tonnes of hazardous waste, or 2,000 tonnes of non-hazardous waste, transferred from their site. ${ }^{8}$ This restricts the group of companies for which information is available to those requiring closer monitoring, in order to keep the management and inspection costs of the registration system to a reasonable level. Meanwhile, while it is true that the facility has to indicate whether the waste will be recovered or disposed of permanently, and this information is available at the company level, the historical series we are using, which is also disaggregated by region, only covers total waste, whether exported for elimination or for recycling. The information on the tonnes of hazardous industrial waste generated in each region (denominator of our dependent variable, HWE) is from the National Statistics Institute's (INE) Encuesta sobre la generación de residuos en el sector industrial (Survey of waste generation in the industrial sector). ${ }^{9}$

Figure 1 of the appendix shows the export intensity of each region to other Spanish regions (HWE), where we can see three facts. First, that all Spanish regions are exporters of hazardous industrial waste. This is because not all of the regions have hazardous industrial waste landfills (as shown in Figure 2 of the appendix), and some of the existing disposal facilities are for a specific type of waste. This in turn makes it possible for regions with disposal facilities to have an export ratio of $100 \%$. Second, there are regions which, while they do not have waste disposal facilities, have a proportion of exported waste below $100 \%$, due to the data sample. As we indicate above, the database used (PRTR-España) shows only waste exported by companies which exceed the export thresholds set in the E-PRTR. And third, almost all waste is exported to other regions within the country, a behaviour which we also see in other developed countries, e.g. the UK or the United States, so that as Jensen (2012) suggests, these subnational flows of hazardous waste are what we should be examining.

\footnotetext{
${ }^{6} \mathrm{http}: / / \mathrm{www} \cdot \mathrm{prtr}-\mathrm{es} . \mathrm{es} / \mathrm{informes} /$ waste.aspx.

7 The guide to methodology for its implementation can be seen at: https://prtr-es.es/Data/images/Gu\%C3\% ADa\%20Implantaci\%C3\%B3n\%20E-PRTR\%20Junio\%202006\%20(en\%20ing1\%C3\%A9s)-0EDE4D9C1E F07E2B.pdf.

${ }^{8}$ As the E-PRTR methodology specifies, these thresholds must be understood as the total sum of the waste transferred off-site, regardless of whether it is kept in the country, transferred to other countries, eliminated or recycled.

${ }^{9}$ https://www.ine.es/jaxi/Tabla.htm?path=/t26/e068/p02/a2009/10/\&file=01001.px\&L=0.
} 
In expression (1), $\delta$ and $\lambda$ are the spatial lag coefficients, which measure the slope of the reaction function or contemporaneous and non-contemporaneous spatial dependence, respectively, i.e., whether the export intensity of waste of a region depends on the present $(\delta)$ and past exports $(\lambda)$ of its neighbouring regions. $\omega_{i j}$ is each element of the spatial weights matrix used to capture the spatial nexus, which we constructed considering neighbours to be the 5 nearest regions in terms of distance, ${ }^{10}$ where $w_{i i}=0$, by definition, and $\omega_{i j} \neq 0$, if the regions $i$ and $j$ interact. $\beta_{w}$ are the coefficients of the variables $y_{i w}$ which capture the characteristic $w$ of the region $i$, and $\alpha_{v}$ are the spatial coefficients of local dependence which capture the spatial effect of the $v$ explanatory variables $z_{j v}$, of the neighbouring regions $j . \mu$ measures the dynamic component or persistence coefficient of export intensity of waste. $\phi_{i}$ captures the specific effect of each region and $\tau_{t}$ the time fixed effect. $\sigma$ is the coefficient of spatial autocorrelation of error, with $u_{i t}=\varepsilon_{i t}$ in the absence of spatial dependence in the error term. We will suppose that $\delta, \lambda, \alpha_{v}$ and $\beta_{w}$ are constant in space and time.

The explanatory hypotheses we used in our model are those identified as such in the literature, and cover economic, institutional, and technological aspects, and the stringency of environmental policies (Fischer et al. 2012; Kellenberg 2015)_in other words, they reflect the different dimensions or theories of waste trade (Glover 2017). The definition of the variables used, and their descriptive statistics are shown in Tables 2 and 3 of the appendix, and the correlations matrix in Table 4 of the appendix.

The first group of explanatory variables relates to the region's control measures and environmental policy, insofar as they may condition the costs of the firms producing/ managing such waste (Fischer et al. 2012). More specifically, our variable of interest is the regional revenue from the tax on industrial waste disposal in landfills, introduced by some Spanish regions, and expressed in terms of the regional volume of generated industrial waste (WTAX). We use this variable as a proxy of the effective tax rate on hazardous industrial waste, ${ }^{11}$ as this may stimulate export intensity of industrial waste from these regions in order to avoid paying the tax (Levinson 1999a, b and 2000; Sasao 2014d; and Kellenberg 2015). ${ }^{12}$ The expected effect is therefore positive. However, taking into account that taxes are not usually applied in isolation but together with other instruments (such as regulations and strict monitoring of waste), and that all these measures can encourage and induce firms to invest and innovate in waste management (Leiter et al. 2011; Kellenberg 2012 and 2015), we have also included the variable WINV. This variable shows the industrial sector investment relating to waste management, understanding that this can measure the result, or be a good indicator, of all the environmental policies (tax-related or not)

\footnotetext{
10 The reference taken was the distances between the region's capitals, leaving aside whether the region borders a foreign country, given that our dependent variable only captures exports to other regions of Spain.

11 No disaggregated information exists on tax revenue corresponding to hazardous industrial waste, so we are using as proxy the total waste tax revenue, provided by the Ministerio de Hacienda (Finance Ministry) in Chapter III, "Impuestos propios" (Own Taxes) of the report "Tributación Autonómica. Medidas" for fiscal years 2002 to 2020 (https://www.hacienda.gob.es/es-es/areas\%20tematicas/financiacion\%20autonomica/ paginas/libro\%20electronico\%20tributacion.aspx).

12 Although constructing the variable WATX in this way has some limitations, we think it is better than approximating it through nominal tax rates, as these are usually different for each type of hazardous waste (with or without recoverable value, etc.), while the regional series of exported waste data provided by PRTR-España, which we use to construct our dependent variable, is aggregated for all hazardous waste. This is also how we can take into account the large tax breaks (exemptions and tax credits) which mean that effective tax rates are quite different to nominal rates. Fikru (2012), for example, also approximates environmental taxes based on tax revenue.
} 
intended to improve industrial waste management. This information is from the Encuesta del gasto de la industria en protección ambiental (Survey of industry spending on environmental protection ${ }^{13}$ by the National Statistics Institute (INE), according to the European Union's Classification of Environmental Protection Activities. The expected sign for this variable is, a priori, negative, because if this investment is allocated to developing recycling technology for a specific type of hazardous waste, the region does not need to export it (Amouzou and Boudier 2016); however, if waste generation is reduced (the denominator of the dependent variable), this could have the opposite effect on the exporting ratio. In line with Çagatay and Mihçi (2003), Kellenberg (2012), Amouzou and Boudier (2016), and Brunel and Levinson (2016), we have also included an indicator of the environmental policy stringency of the region (STRINGENCY), which, for the same reasons as WINV, we expect to have an indeterminate influence on export intensity of waste. We have approximated this variable through total spending (current costs and investment) on environmental protection carried out by the industries of each region, insofar as such spending is the result of the public environmental policies adopted in that region.This information was obtained from the Encuesta del gasto de la industria en protección ambiental (Survey of industry spending on environmental protection) by the National Statistics Institute (INE), in response to the European Union's requests for information on environmental protection.

The variables STRINGENCY, WTAX, and WINV are all expressed in terms of the volume of generated industrial waste in each region, given that they are intended to measure the effective cost of tax and environmental protection policies borne by industrial firms per unit of industrial waste produced, whatever their nature (hazardous or non-hazardous), as such policies usually affect industrial waste as a whole, and no specific information on hazardous waste is available. And to check whether the tightening up of the agreements governing the international trade in hazardous industrial waste (European Environment Agency 2012; Kellenberg and Levinson 2014; Glover 2017), and especially the EU obligation to treat waste in or near the jurisdiction of origin, had led to external exports (to other countries) switching to or being replaced by internal traffic in waste (between Spanish regions), we included the rate of exportation of hazardous industrial waste to other countries (TRADE-OFF) as an explanatory variable, for which we would expect to obtain a negative sign (Levinson 1999b).

The second group of explanatory variables relates to the regional structure of production, insofar as the more weight the industrial sector has in the region, the greater its export intensity will be (Levinson 2000; and Jensen 2012). ${ }^{14}$ Specifically, we have included the number of industries per square kilometres or industrial agglomeration in the region (AGGLO), for which we would expect to obtain a positive sign; and its interaction with the relative importance of the industrial sector (INDW), with which we hope to approximate the presence of economies of scale in industrial waste management (recycling or value recovery). In line with the reasoning of Brülhart and Mathys (2008) and of Amouzou and Boudier (2016), a negative sign for this interaction could suggest the appearance of a growing waste management capacity, with a consequent reduction in the need to export waste to other regions. We have also included the intensity of industrial waste generation (POLLUTANT), measured as the amount of waste generated per unit of industrial production,

\footnotetext{
13 https://www.ine.es/dynt3/inebase/index.htm?type=pcaxis \&path=/t26/p070/p01/serie/ \&file $=$ pcaxi $\mathrm{s} \& \mathrm{~L}=0$.

14 Rather than information for the industrial sector, some papers use national income to capture the size of the economy (Baggs 2009; Kellenberg 2015; Amouzou and Boudier 2016).
} 
to attempt to identify the regions where the most polluting industrial activities are concentrated, understanding that this may condition its waste export rate. For the same purposes, we have also included industry size (SIZE), since, as McGlinn (2000) indicates, large industries are responsible for much of the waste generated, although as they usually manage their waste themselves, the expected sign for this variable is initially undetermined. Following the approaches of Jensen (2012) and Amouzou and Boudier (2016), we have also considered two additional variables relating to waste management capacity: the percentage of industrial waste which is reused (VALORIZ), and the percentage of recycling companies in the region (RECYC). The expected sign of both variables, a priori, is negative, as the greater the region's installed capacity for waste recycling and value recovery, the lower the need to export waste should be.

The third group of explanatory variables comprises intensities of use, in terms of industrial production, of the factors of production energy (ENERGY), labour (SALARY) and capital (CAPITAL), although given the strong correlation between capital endowment and regional income, we have used spending on $R \& D$ as a proxy for capital endowment. The expected sign for CAPITAL is indeterminate a priori. On the one hand, the capital-intensive sectors can be associated with more innovative, less-polluting activities, so the comparative advantage in terms of capital intensity would give them sufficiently advanced technology to maximise the efficiency of waste management and specialise in it (e.g. Cole and Elliot 2003; Glover 2017), and they would tend to export less waste (following this line of thought, labourintensive regions -SALARY- would tend to export more waste). On the other hand, many industries are capital-intensive but highly polluting (e.g. chemicals, steel, etc.) for whom, as Kellenberg (2012) indicates, the marginal cost of exporting waste may be smaller than the cost of building new waste facilities at home or relocating entire production facilities to a foreign country. Similarly, energy consumption (ENERGY) could capture a greater use of new capital assets, more efficient and less polluting, but it could also be a symptom of antiquated production processes, energy-intensive and highly polluting (Balsalobre-Lorente et al. 2019).

The last group of variables used captures the region's socioeconomic characteristics. Although a country's income or production has typically been used in the literature as an argument for exploring the Pollution Haven Hypothesis or the Waste Haven Effect, our proposal goes beyond this traditional approach, as we want to analyse not only whether the pattern of waste trading between rich and poor countries (the waste haven effect) was being reproduced at the regional level in Spain; we also want to see if the industrial waste exporting behaviour of Spanish regions is compatible with the EKC hypothesis. For this reason, we include both income (INCOME) and its square. Income is expected to have a positive effect on export intensity of waste, as it is a scale effect estimation, although if the effects of changes in the composition of the product and the technology exceed the scale effect, the elasticity of export intensity in relation to income level will be negative. And on the same line as Levinson (1999a, b), Jensen (2012), and Sasao (2014d), we also include the percentage of population in towns under 1,000 inhabitants (RURAL) and the average years of schooling (SCHOOLING). Both variables enable us to approximate the environmental awareness levels of these collectives (which would be low in the case of the generally older rural population, and high among the more educated population); but also the level of dynamism and industrial activity of these regions (low in rural areas, with an ageing population and low density, ${ }^{15}$ and high in areas with high education levels). The expected signs for these two variables are therefore indeterminate.

\footnotetext{
${ }^{15}$ Balsalobre-Lorente et al. (2019) also point out that technological advances with a positive impact on the environment take place in cities (technique effect).
} 


\section{Results}

When implementing the model, we lagged the variables WTAX, WINV, and STRINGENCY, in order to take into account the probable delayed impact of environmental monitoring and policies (Levinson 1999a and 2000; Cole et al. 2010). Also, as the literature has shown the possible causal relationship between pollution and environmental regulations and taxes (e.g. Levinson 2000), and between pollution and waste treatment capacity (e.g. Amouzou and Boudier 2016), we tested the potential endogeneity of the variables relating to environmental policies (WTAX, WINV and STRINGENCY) ${ }^{16}$ and relating to waste treatment capacity (VALORIZ and RECYC). Besides, we also tested the potential endogeneity of TRADE-OFF, as we thought there might be a causal relationship between the rate of exported waste (to other regions) and external exports (to other countries). To do this, we followed the two-stage Hausman procedure, using, among others, the lagged variables themselves as instruments, but the results (Durbin-Wu-Hausman statistics) suggested that we cannot reject the null hypothesis of exogeneity in any of these variables because the $p$-value associated with the Hausman (1978), Durbin (1954), and Wu-Hausman (Wu 1974 and Hausman 1978) endogeneity test statistics are over 0.05. The Sargan (1958) and Basmann (1960) tests also indicated that we cannot reject the null hypothesis of validity of the instruments used. All of these tests are shown in Table 5 of the appendix.

The Pesaran and Moran tests, shown in Table 6 of the appendix, confirm the hypothesis of spatial dependence of the hazardous industrial waste exportation model we had proposed, and which Jensen (2012) suggested, as the null hypothesis of spatial independence is rejected, with the $p$-value less than 0.05. Moreover, the average absolute value of the off-diagonal elements is 0.4 , which is a very high value, so that there is enough evidence suggesting the presence of cross-sectional dependence (Hoyos and Sarafidis 2006) in (1). Thus, for the estimators to be consistent, we had to use spatial dependence models.

Table 7 of the appendix shows the different spatial dependence models we considered in our analysis. Although the results do not differ substantially, according to the model selection procedure proposed by Elhorst (2012), and shown in Table 8 of the appendix, the best model for explaining the rate of exportation of hazardous waste of the Spanish regions had to capture the spatial correlation in the endogenous variable and explanatory variables -in other words, it had to be a dynamic spatial Durbin model (dynamic SDM). Therefore, our estimate, with panel data and fixed regional and temporal effects, is a dynamic SDM for the period 2007-2017, which is estimated using quasi-maximum likelihood ( $Q M L)$ techniques (Wooldridge 2010) and Driscoll-Kraay standard errors, which produce heteroscedasticityrobust estimators for panel regressions with cross-sectional dependence (Hoechle 2007). ${ }^{17}$

The results of the selected model, which can be seen in Table 1 as Model 1, suggest that indeed, export intensity of hazardous industrial waste shows dynamic behaviour ( $\mu$ ) growing over time, such that a region's current industrial waste export rate depends positively on its past exporting behaviour. This result contradicts Levinson (1999b), who without

\footnotetext{
${ }^{16}$ However, introducing these lagged variables reduced possible endogeneity problems considerably. Also, many environmental regulations originate in the EU, guaranteeing a kind of natural experiment (Brunel and Levinson 2016).

17 Quasi-maximum likelihood $(Q M L)$ techniques use a statistical model that is formed by maximizing a function that is related to the logarithm of the likelihood function, but in discussing the consistency and (asymptotic) variance-covariance matrix, they assume some parts of the distribution may be mis-specified. The Driscoll-Kraay approach provides a specific variant of the Newey-West robust covariance estimator computed using the Bartlett kernel and a time series of scores' cross-sectional averages (Belotti et al. 2017).
} 
using a dynamic model, finds a constant reduction in the disposal of waste outside the territory where it was generated. Also, the existence of spatial nexuses in the waste export rate is confirmed for Spain. Jensen (2012), the only paper to have considered the existence of nexuses to date, did not find them in its spatial model for the United Kingdom. Specifically, the global spatial dependence coefficients, $\delta$ and $\lambda$, show that higher export intensity of industrial waste in neighbouring regions (today and in the past) are associated with higher export intensity in the region itself ( 0.37 and 0.42 , respectively), and these results are consistent with the value of the off-diagonal elements of the Pesaran test (0.4). The geographical concentration which characterised Spain's industrialisation process, and which was made more acute by territorial specialisation and agglomeration strategies (Figure 3 of the appendix), could explain this spatial correlation. ${ }^{18}$

Table 1 also shows that all the hypotheses proposed in our model were found to be relevant for explaining the dependent variable. As expected from a theoretical point of view and empirically demonstrated, a more severe waste tax (WTAX) and more stringent environmental regulations (STRINGENCY) mean a higher waste export rate or, to put it another way, relatively lower local disposal, seeking to avoid these taxes and regulations (Levinson 2000; Sasao 2014d). However, given the small coefficients of both variables, the influence of these policies seems to be fairly low in the Spanish case, which may be due to the low tax rates; to the location and specialisation of hazardous industrial waste disposal facilities; and as Glover (2017) suggests, to poor compliance with environmental regulations. Nevertheless, business investments relating to waste management (WINV) do not seem to be influencing the waste export rate, which could be understood in a context of negligible and falling levels of investment in environmental protection, as seen in Spain after the international economic crisis of 2007. This can be seen in Figure 4 of the appendix, which shows a considerable fall in investment in environmental protection starting in 2008, from which Spain has yet to recover; and in Figure 5 of the appendix, which shows that waste management is the environmental area that receives the least investment from Spanish industries, representing just $5.7 \%$ of the total (equivalent to $0.4 \%$ of the turnover of these industries).

The waste export rate of a region also seems to depend to some degree on the environmental policies established by neighbouring regions ( $\omega$ WTAX, $\omega$ STRINGENCY and $\omega \mathrm{WINV})$, although their effect is also very small, and $\omega$ WINV is significant only at $10 \%$. Kellenberg (2012) and Amouzou and Boudier (2016) obtain a similar result, although without using a spatial econometric model. The local spatial dependence, $\alpha$, captured by these variables could be explained by the Pollution Haven Hypothesis, given that when a region adopts restrictive environmental policies, not only can this incentivise export intensity of waste, as suggested by the positive sign for these variables in the same region (TAX and STRINGENCY); it can also disincentivise its specialisation in polluting activities, and these activities may end up moving to neighbouring regions (Stern et al. 1996 and Kellenberg 2012), who will be the ones polluting and producing exportable waste, which would be reflected in the positive sign for these variables in the neighbouring regions ( $\omega$ TAX and $\omega$ STRINGENCY). Thus, positive coefficients of $\omega$ WTAX and $\omega$ STRINGENCY

\footnotetext{
18 To test the robustness of our results, we considered other definitions for the weighting matrix, considering neighbours to be the 2,3,4,5,6, or 7 nearest regions in turn. Although the significance of some variables is sensitive to the matrix considered, as can be seen in Table 9 of the appendix, the results did not vary significantly, and the spatial nexus and temporal persistence are a constant in all the cases considered.
} 
Table 1 Results of estimating hazardous industrial waste exports (dynamic SDM)

\begin{tabular}{|c|c|c|c|}
\hline & Model 1 & Model 2 & Model 3 \\
\hline Dynamic component $(\mu)$ & $.7610298 * * *$ & $.8060641 * * *$ & $.752023 * * *$ \\
\hline WTAX & $.0016746 * * *$ & & $.0018617 * * *$ \\
\hline WINV & -.0008827 & -.0011816 & -.0006195 \\
\hline STRINGENCY & $.0118527 * * *$ & $.0125495 * * *$ & \\
\hline TRADE-OFF & $-.000813^{* * * *}$ & $-.0007165^{* *}$ & $-.000851^{* * *}$ \\
\hline VALORIZ & $-.0065 * * *$ & $-.007730 * * *$ & $-.0061529 * *$ \\
\hline RECYC & -.0068302 & -.0038118 & $-.0149541 *$ \\
\hline POLLUTANT & $.0050448 * *$ & $.0047374 *$ & $.0049903 * *$ \\
\hline AGGLO & $.1637796^{* *}$ & $.1401269^{*}$ & $.1910532 * * *$ \\
\hline AGGLO * INDW & $-.0407569 * *$ & -.0254727 & $-.051573^{* * *}$ \\
\hline SIZE & .0077132 & .0108305 & .0033404 \\
\hline ENERGY & $-.0883027 * * *$ & $-.096266^{* * *}$ & $-.078456^{* * *}$ \\
\hline SALARY & $.4928413 * *$ & $.4430587 *$ & $.5321593 * *$ \\
\hline CAPITAL & $-.0891497 * * *$ & $-.080811 * * *$ & $-.086505^{* * *}$ \\
\hline INCOME & $1.882795 * * *$ & $1.957691 * * *$ & $1.760681 * * *$ \\
\hline $\mathrm{INCOME}^{2}$ & $-.260905^{* * *}$ & $-.284215^{* * *}$ & $-.241837 * * *$ \\
\hline RURAL & .0279938 & $.0325423^{*}$ & .026379 \\
\hline SCHOOLING & 6199749 & $.6920693^{*}$ & $.6201992 *$ \\
\hline \multicolumn{4}{|l|}{ Spatial coefficient of local dependence $(\alpha)$} \\
\hline$\omega \mathrm{TAX}$ & $.0091989 * *$ & .0045474 & $.009763 * *$ \\
\hline$\omega I N V$ & $.0091694^{*}$ & $.0092032 *$ & $.0082405^{*}$ \\
\hline$\omega$ STRINGENCY & $.0227813 * * *$ & $.0255523 * * *$ & $.0118004 *$ \\
\hline$\omega \mathrm{RECYC}$ & -.0766402 & -.0717266 & -.0790173 \\
\hline$\omega I N C O M E$ & -.5339158 & -.6136451 & -.4643425 \\
\hline Spatial correlation coefficient $(\delta)$ & $.3702973 * * *$ & $.3251636^{* *}$ & $.3530322 * *$ \\
\hline Space-time lagged dependent variable $(\lambda)$ & $.4210435 * * *$ & $.5592225 * * *$ & $.3278295 * *$ \\
\hline Variance sigma2_e & $.0004478 * * *$ & $.0004577 * * *$ & $.000457 * * *$ \\
\hline $\mathrm{R}_{\mathrm{w}}^{2}$ & 0.5062 & 0.4961 & 0.5127 \\
\hline Observations & 170 & 170 & 170 \\
\hline
\end{tabular}

*Significant at $10 \%$ level, **significant at $5 \%$ level, ***significant at $1 \%$ level

may reflect a displacement or crowding-out effect, pushing polluting industrial activities towards neighbouring regions, which then become more intensive centres of waste exports.

Our model also suggests that Spain's compliance with the Basel Convention ${ }^{19}$ and the guiding principles of EU policy on proximity in waste treatment has led the Spanish regions to change the destinations of their waste exports, given that there seems to be a TRADE-OFF between external and internal export intensity.

Like Levinson (1999a, b), Kellenberg (2012), and Amouzou and Boudier (2016), our results indicate that the more capacity a region has to recover value from waste (VALORIZ), the less need it has to export it; although the recycling capacity of neighbouring regions (RECYC) does not seem to be relevant. Also, the regions with the most polluting

19 Intended to stop the most toxic and hard-to-recycle materials being exported to developing countries. 
industrial sectors (POLLUTANT) and with the greatest industrial agglomeration (AGGLO) show a higher waste export rate, in line with Jensen (2012), who finds a direct relationship between the size of the industrial sector (in terms of employment) and waste flows, although this relationship is no longer significant with her spatial econometric model. However, the negative sign obtained when we interact AGGLO and INDW may suggest the presence of economies of scale in waste management, due to the concentration of economic activity, and thus the development of a growing waste management capacity, which could lead to limiting the export intensity of waste. This result would fit with the argument of Levinson (1999a, b), who suggests that in a context of returns to scale in waste management and disposal, and regions with large waste-generating companies which are more likely to have their own waste disposal facilities, waste will be proportionately less likely to be exported from high-polluting jurisdictions. However, company size SIZE) is not found to be relevant in our model.

The results obtained for inputs also fit what was expected from a theoretical point of view, and from what is shown by part of the empirical literature. In line with the results obtained by Baggs (2009), regions specialising in activities that are capital-intensive (CAPITAL) and energy-intensive (ENERGY) show a lower waste export rate, while in regions with labour-intensive industries (WAGE) the export rate is higher. Cole et al. (2010) and Kellenberg (2012), however, do not find significant evidence of this, ${ }^{20}$ although in a context other than waste exports, Higashida and Managi (2014) find that the higher per capita salaries are in an importer country, the more recyclable waste it will import.

With due caution, the positive sign of the coefficient of regional income (INCOME) could be understood as an indirect indicator that the pattern of trade between rich and poor areas or waste haven effect which Baggs (2009) and Kellenberg $(2012,2015)$ find at the international level, and Jensen and McIntyre (2010) detected weakly in Wales, ${ }^{21}$ is happening inside Spain. ${ }^{22}$ Also, as Balsalobre-Lorente et al. (2019) find, export intensity of waste shows a behaviour in line with EKC, as the negative sign of the square of the variable INCOME puts Spanish regions on the upward slope of the Kuznets curve, but with relative decoupling. However, the average per capita income in Spain is €22,792, so it seems that we are far from reaching the turning point, which our model puts at around $€ 36,899$ per capita. An illustration of the EKC for the hazardous industrial waste export rate in Spain can be seen in Figure 6 of the appendix.

Although the literature has found the urban or rural nature of the regional population, and its education level, to be relevant in explaining waste trading (Levinson 1999a, b; Jensen 2012), our model did not prove sensitive to these variables (RURAL and SCHOOLING). ${ }^{23}$

\footnotetext{
20 This may be due to the different methodology used; the different way these variables are measured; the different scenario, sample, and period analysed; or simply because our analysis only includes hazardous industrial waste.

21 Other works (e.g. Higashida and Managi 2014) find that less-developed countries import waste as a means of economic development.

22 In fact, as we mention above (Figure 2 of the appendix), hazardous waste landfills tend to be mostly located in Spain's less developed regions. In any case, to be able to state with confidence the existence of a waste haven effect, import flows should be taken into account, although the lack of data on this aspect makes a study of this kind impossible.

23 We also tried including variables which had been relevant in other papers, such as population or population density (Glover 2017; Jensen 2012), although they did not enable us to improve the model.
} 
Finally, we estimated the model excluding some key variables, WTAX or STRINGENCY (models 2 and 3 on Table 1). However, the results showed hardly any variation, which can be a sign that the model used is robust.

\section{Concluding Remarks}

Little attention has been paid in the literature to flows of hazardous industrial waste, especially those that happen inside a country, despite the fact that analysis at the subnational level provides a fairly homogeneous context for study in terms of the institutional framework and the statistical quality of information; that quantitatively, regional flows of waste are much larger, in relative terms, than international flows (especially in the European sphere); and that as Jensen (2012) points out, examining subnational hazardous waste flows is more informative to modellers and policymakers than research focusing on international hazardous waste flows.

For this reason, in this paper we study the determinants of the subnational trade in hazardous industrial waste, paying particular attention to whether regional industrial waste taxes and environmental policies encourage the export intensity of this type of waste. Also, our study is the first to analyse this matter while monitoring the spatial nexuses and the dynamic component underlying export intensity of hazardous industrial waste, and thus makes a clear contribution to the literature. We do this using a dynamic SDM, given that spatial dependence has been shown to exist in the endogenous and explanatory variables, but not in the error term. The study scenario comprises the 17 Spanish regions and the period 2007-2017, a relevant and serviceable sample, given that nine of the regions have taxes on industrial waste generation, and all of them have environmental taxes and regulations, in line with national and EU policy.

The results of the model show, on one hand, first, that strict environmental policies, including waste tax, encourage export intensity of industrial hazardous waste. Second, industrial/production structure and socio-economic factors influence the export rate of this type of waste, in line with theoretical predictions in the existing literature. Third, the regions do not behave independently when exporting their waste; a region's waste export intensity depends on the export intensity of its neighbouring regions $(\delta)$, and this spatial interaction extends over time $(\lambda)$. The model also shows evidence of spatial spillover effects for environmental policy ( $\omega$ WTAX, $\omega$ STRINGENCY). Therefore, if we want to control the flow of industrial waste, it would probably be more productive to tackle the problem together, rather than launch regional or individual initiatives, e.g., it would be advisable for taxes on industrial waste generation to be applied nationally (to internalise these spillover effects), or even supranationally. This would help to reduce the displacement of production or polluting waste between regions, or between the countries of a trading area, such as the European Union, and consequently lower the efficiency costs of eco-dumping generated by the existence of jurisdictions where waste disposal is not taxed, enabling greater compliance with the European Union's "polluter pays" principle. However, these waste taxes are not a panacea. We should not forget that although the location and specialisation of hazardous industrial waste disposal facilities in Spain enables them to realise scale economies in the recycling industry, and pollution from waste can be minimised by gathering waste in one place, they probably impede the effectiveness of waste taxes for disincentivising waste exports. Moreover, waste taxes can encourage illegal dumping, which can be much more harmful to the environment than legal waste disposal (EEA 2012). For this reason 
they must be accompanied by efforts to install more hazardous industrial waste disposal facilities, develop other waste management options, implement more frequent and strategic inspections, and introduce new technologies for tracking the movement of waste. It must also be remembered that a decentralised implementation of these taxes can lead to a race to the top to offset the high costs and few benefits of waste disposal. However, as decentralised management is the only way to allow adaptation to environmental preferences which vary from region to region (or from country to country), it could be advisable to empower jurisdictions to set the environmental policies and standards they deem necessary to protect the health and environment of their citizens, while respecting minimum federal or supranational standards of environmental regulation and taxation. At the same time, economic policies on waste management must be strengthened, as this is the area of environmental protection receiving the least investment. This appears to be the goal of the draft Law on Waste and Polluted Soil (transposing the 2018 directive on waste and the directive on single-use plastics), the Spanish Circular Economy Strategy (EEEC), España Circular 2030, and the Royal Decree-Law improving the traceability and monitoring of waste transport, recently approved by the Government of Spain.

Fourth, our model suggests that export intensity of industrial waste exhibits dynamic behaviour $(\mu)$ and is closely linked to regional income (INCOME), although the non-linear relationship between both variables would place the Spanish economy on the upward slope of the EKC but with relative decoupling. Nevertheless, given the high degree of persistence $(\mu)$ shown by the dependent variable and the moderate value of the squared INCOME coefficient, plus the negligible effect on containing the flow of waste of the region's capacity to recover value (VALORIZ), the use of capital (CAPITAL) and energy (ENERGY) in production processes, and economies of scale in the management of wastes arising from the concentration of economic activity (AGGLO*INDW), it seems clear that measures should be implemented in Spain which can intensify the relative decoupling which appears to be emerging between industrial development and waste exports. The use of new technologies in value recovery and recycling which can give waste products a second life, and advanced technologies to reduce waste generation, can contribute to this; both are key elements of the circular economy and EU environmental strategy. If this is not possible, enough hazardous industrial waste disposal facilities must be provided to enable waste management in or near the region of origin, in line with EU regulations. Nevertheless, the idea is not to prohibit the trade in hazardous waste, ${ }^{24}$ but to avoid its transportation by firms seeking to avoid the costs of appropriate management of such waste. Also, our model suggests that international agreements and European regulations are incentivising a switch from exporting to third countries to internal flows of waste between the Spanish regions (TRADEOFF), which could prompt the need for new waste treatment facilities to assimilate this trade-off.

Although the lack of information at the regional level on the volume of hazardous industrial waste imported shaped the study for this paper, which could only examine exports, we were able to draw significant conclusions which represent a contribution to the literature, such as the dynamic nature and spatial dependence relationship which appear to characterise flows of this type, as well as the influence of certain variables, such as environmental policies, the industrial/production structure and socio-economic factors.

\footnotetext{
24 The fact that not all jurisdictions have industrial waste treatment plants, probably for reasons of profitability and a lack of the necessary technology, makes waste flows between jurisdictions inevitable.
} 


\section{Appendix}

See Appendix Figs. 1, 2, 3, 5, 6 and Tables 2, 3, 4, 5, 6, 7, 8, 9.4,

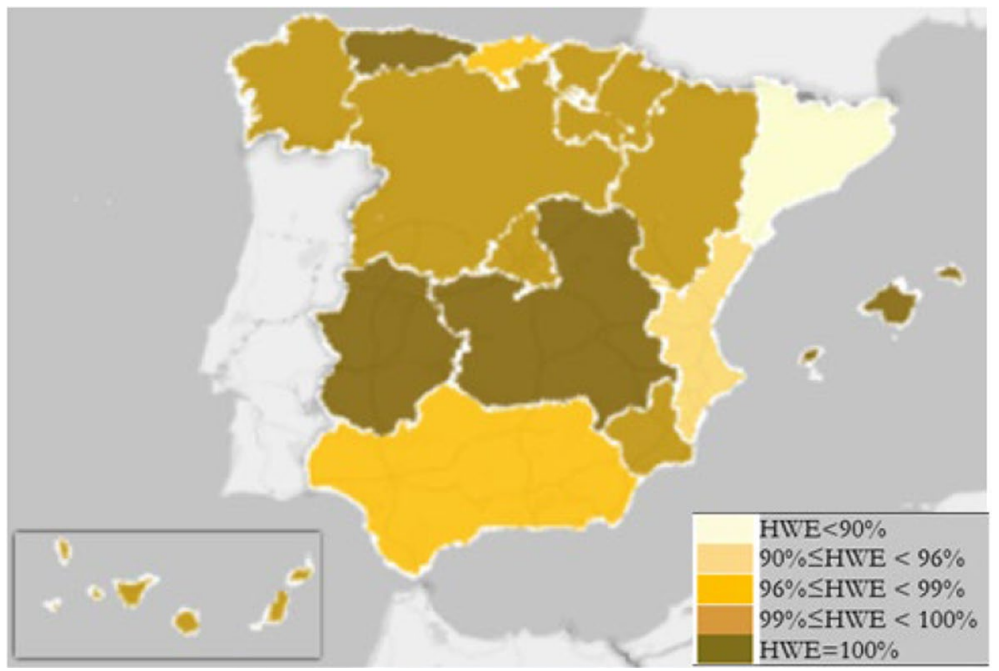

Fig. 1 Percentage of waste exported by each region to other regions Source: By the authors, based on data obtained from the State Pollutant Release and Transfer Register (PRTR-España) and the Survey of waste generation in the industrial sector (INE)

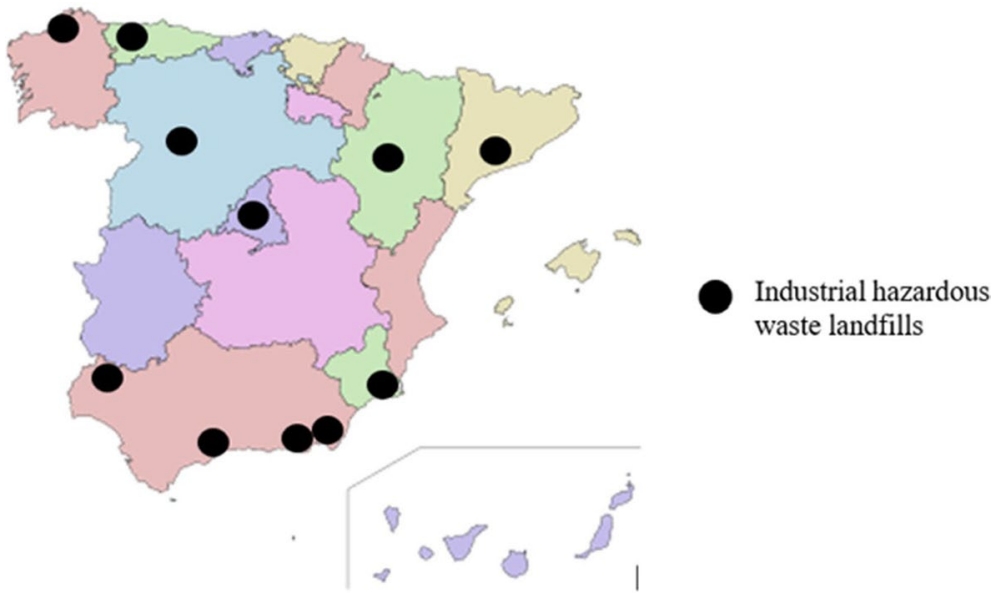

Fig. 2 Location of the hazardous industrial waste disposal facilities Source: By the authors, based on Mora and Dvorzhak (2016) 


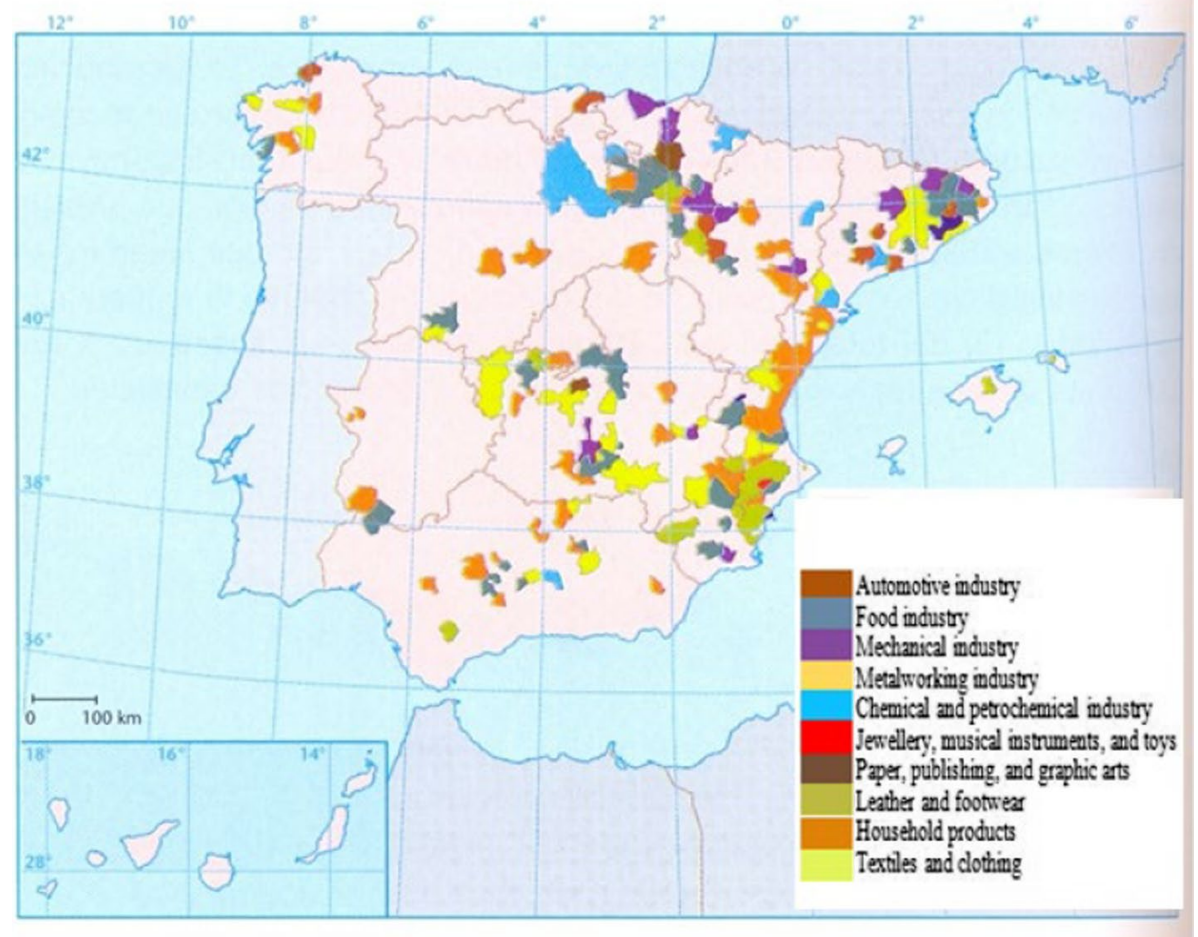

Fig. 3 Location of industry by sectors of activity. Source: https://ecojovenblog.wordpress.com/2016/11/09/ primera-entrada-del-blog/

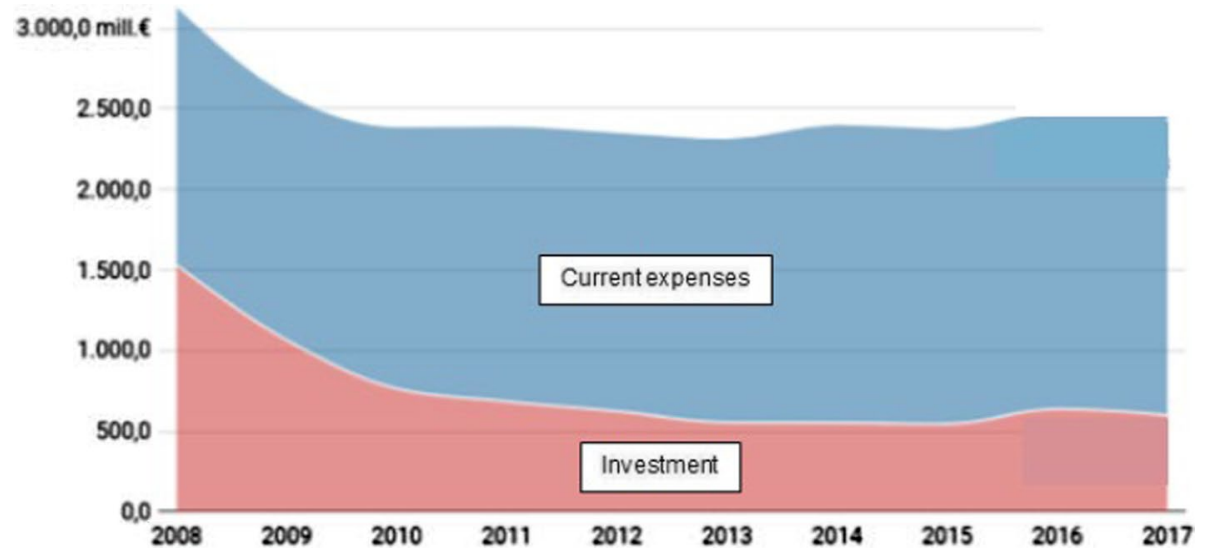

Fig. 4 Investment in and current expenditure on environmental protection by industry Source: Instituto Nacional de Estadística (INE) 
$61.9 \%$

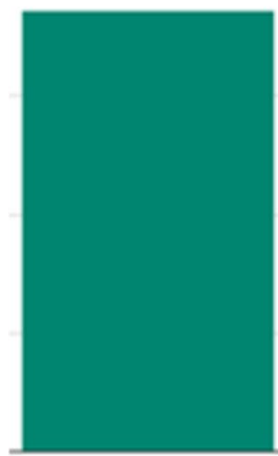

$16.8 \%$

$15.6 \%$

Air and climate protection

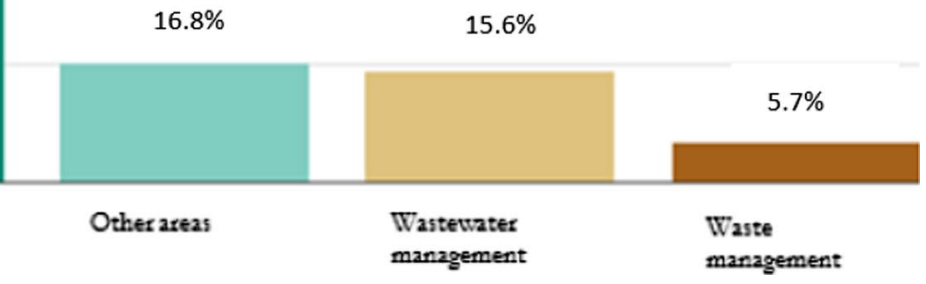

Fig. 5 Investment by industry in environmental protection in 2017, by environmental area (\% of total investment in environmental protection) Source: Instituto Nacional de Estadística (INE)

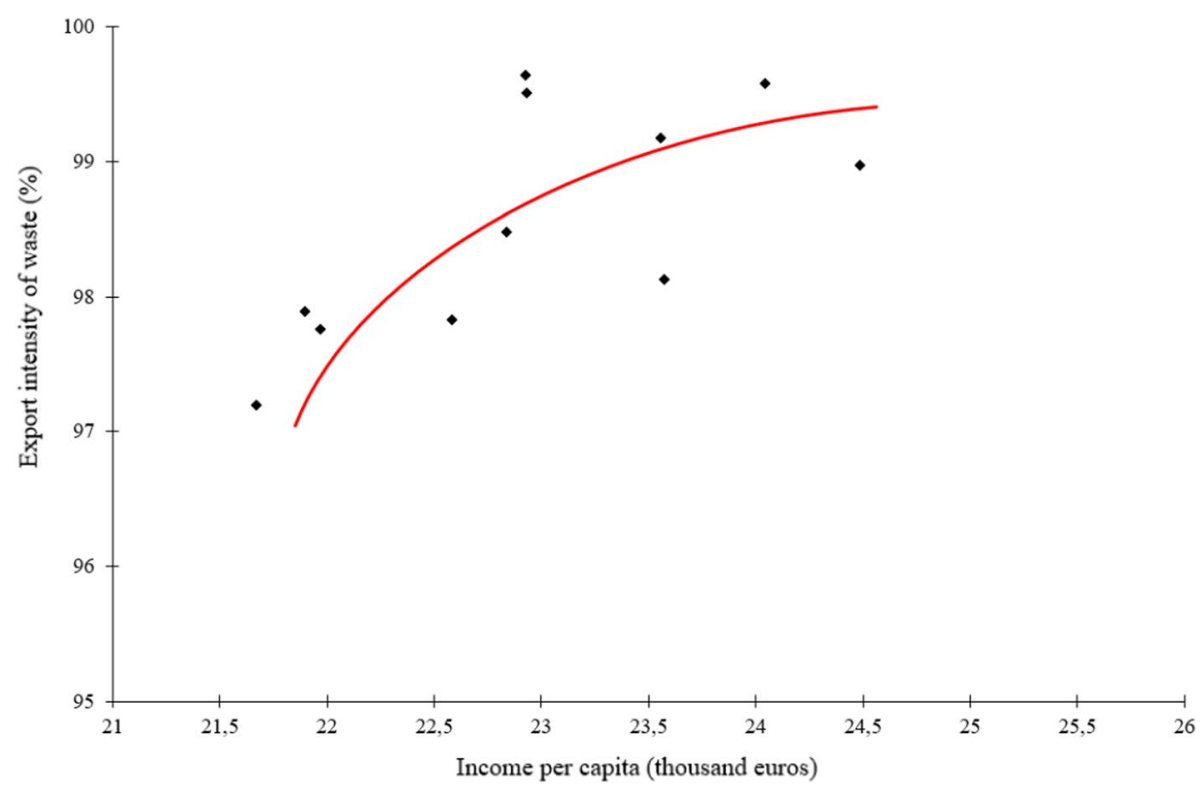

Fig. 6 Environmental Kuznets Curve for the waste export rate in Spain Source: By the authors 


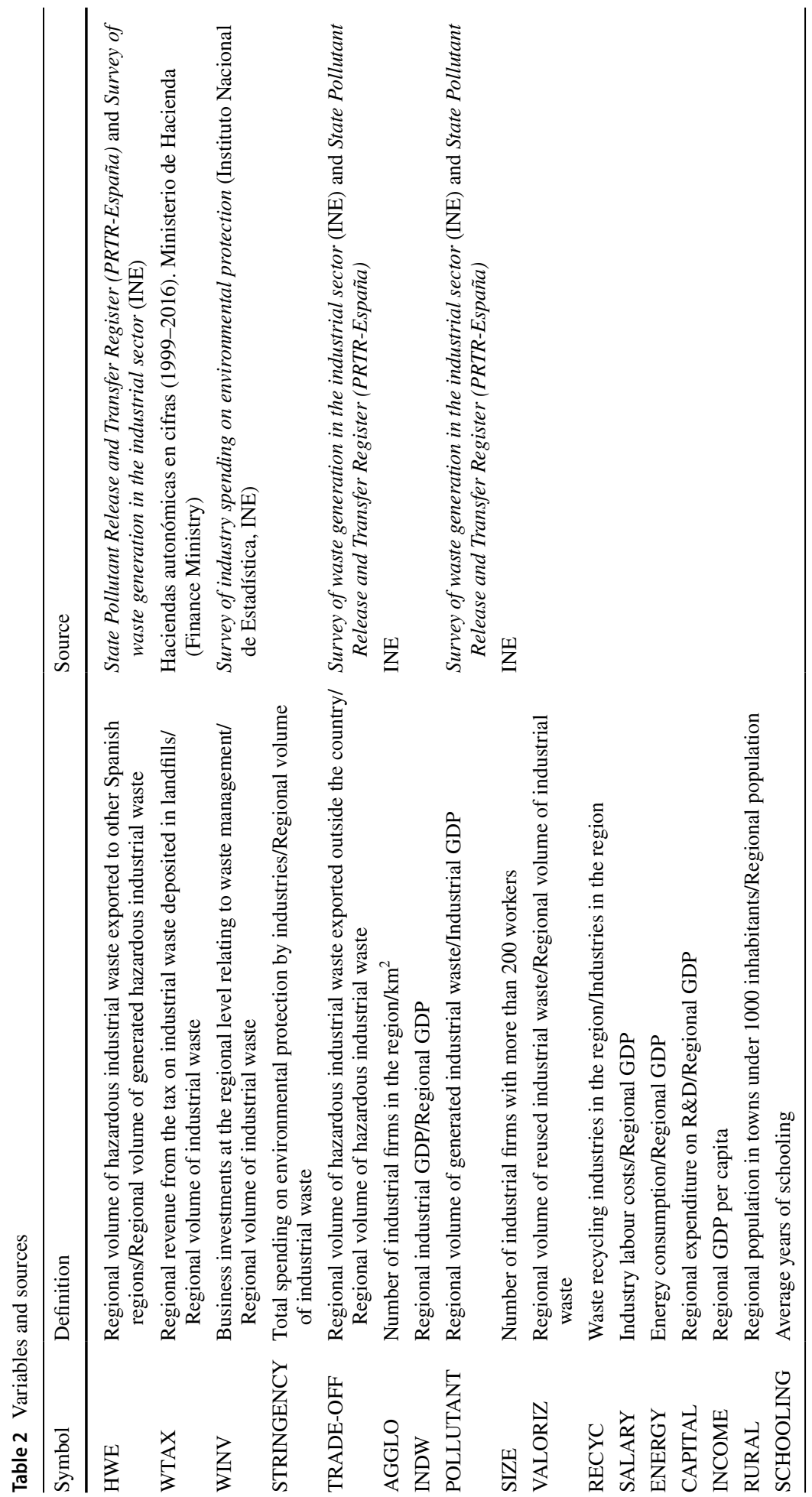


Table 3 Descriptive statistics of the variables

\begin{tabular}{lrrrrc}
\hline Variable (unit) & Obs & Mean & Std. Dev & Min & Max \\
\hline HWE (Percentage) & 170 & 98.50 & 4.55 & 69.90 & 100 \\
WTAX (Thousands of euros/Tonnes of waste) & 170 & 0.29 & 1.11 & 0.00 & 8.83 \\
WINV (euros/Tonnes of waste) & 170 & 2.67 & 4.64 & 0.01 & 41.79 \\
STRINGENCY (euros/Tonnes of waste) & 170 & 26.91 & 22.98 & 6.16 & 135.56 \\
TRADE-OFF (Percentage) & 170 & 0.01 & 0.04 & 0.00 & 0.30 \\
AGGLO (Industries/km2) & 170 & 0.74 & 0.73 & 0.11 & 3.43 \\
INDW (Percentage) & 170 & 19.50 & 6.83 & 7.13 & 33.16 \\
POLLUTANT (Tonnes of waste/Thousands of euros) & 170 & 0.12 & 0.12 & 0.00 & 0.83 \\
SIZE (Units) & 170 & 73.87 & 83.84 & 4.00 & 402.00 \\
VALORIZ (Percentage) & 170 & 45.30 & 18.93 & 0.7146 & 89.28 \\
RECYC (Percentage) & 170 & 0.11 & 0.02 & 0.07 & 0.19 \\
ENERGY (Percentage) & 170 & 0.03 & 0.01 & 0.01 & 0.05 \\
SALARY (Percentage) & 170 & 47.56 & 2.36 & 42.39 & 53.71 \\
CAPITAL (Percentage) & 170 & 1.08 & 0.47 & 0.32 & 2.24 \\
INCOME ( $€$ ) & 170 & 22,792 & 4,499 & 15,441 & 33,320 \\
RURAL (Percentage) & 170 & 0.05 & 0.05 & 0.00 & 0.19 \\
SCHOOLING (Units) & 170 & 9.59 & 0.63 & 8.14 & 11.58 \\
\hline
\end{tabular}




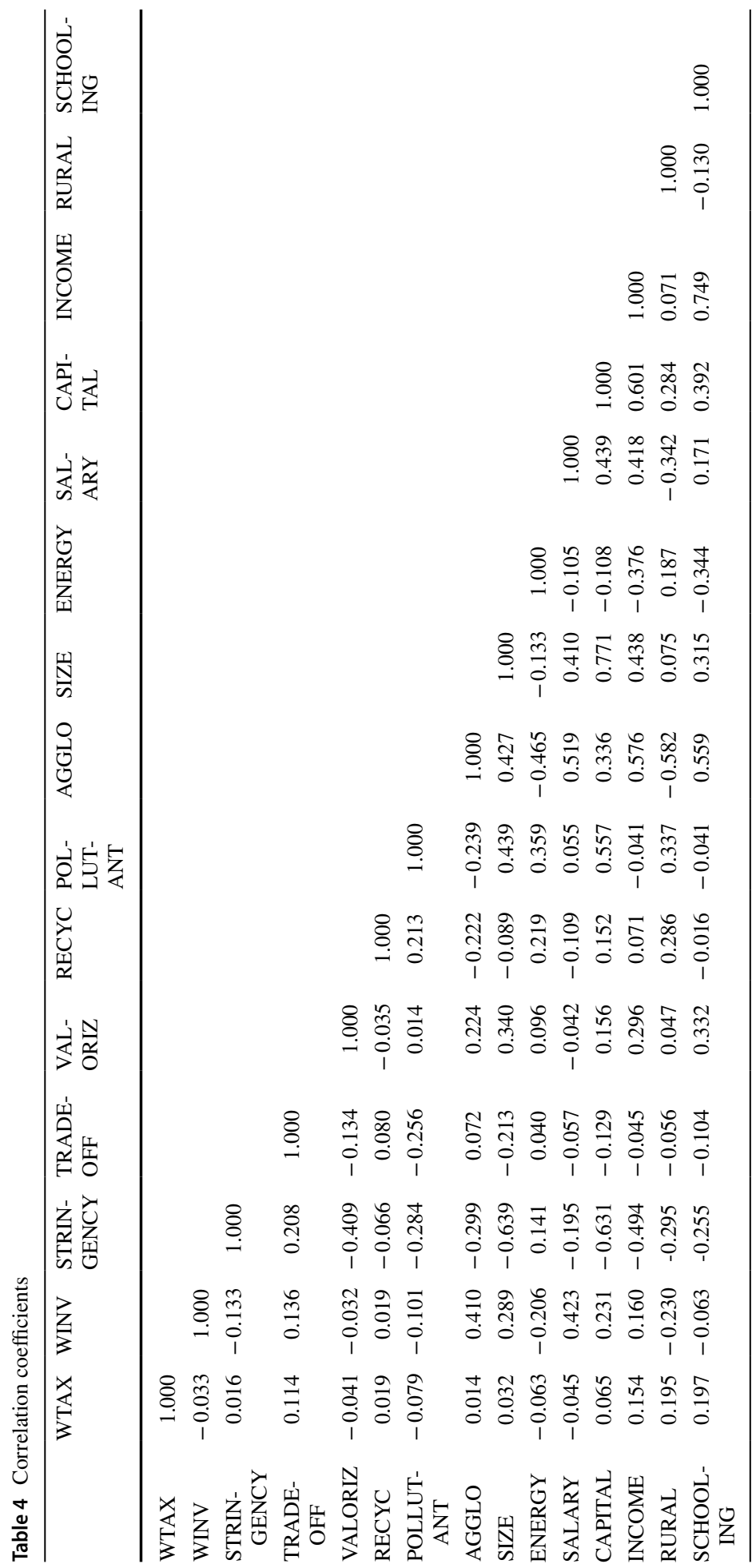


Table 5 Analysis of potential endogeneity

\begin{tabular}{llllll}
\hline Variable & $\begin{array}{l}\text { Hausman } \\
\text { (endog) } \\
\text { Prob }>\mathrm{X}_{\mathrm{i}}^{2}\end{array}$ & $\begin{array}{l}\text { Durbin } \\
\text { (endog) } \\
\text { Prob }>\mathrm{X}_{\mathrm{i}}^{2}\end{array}$ & $\begin{array}{l}\text { Wu-Hausman } \\
(\text { endog) Prob }>\mathrm{F}\end{array}$ & $\begin{array}{l}\text { Sargan } \\
\text { (overid) } \\
\text { Prob }>\mathrm{X}_{\mathrm{i}}^{2}\end{array}$ & $\begin{array}{l}\text { Basmann } \\
\text { (overid) }\end{array}$ \\
\hline Prob $>\mathrm{X}_{\mathrm{i}}^{2}$
\end{tabular}

Table 6 Test of cross-sectional dependence
Pesaran test $(\mathrm{Pr})$

Absolute average value of the off-diagonal elements

Moran MI error test (Pr)
$3.372(0.0007)$

0.400

$5.2089(0.000)$ 


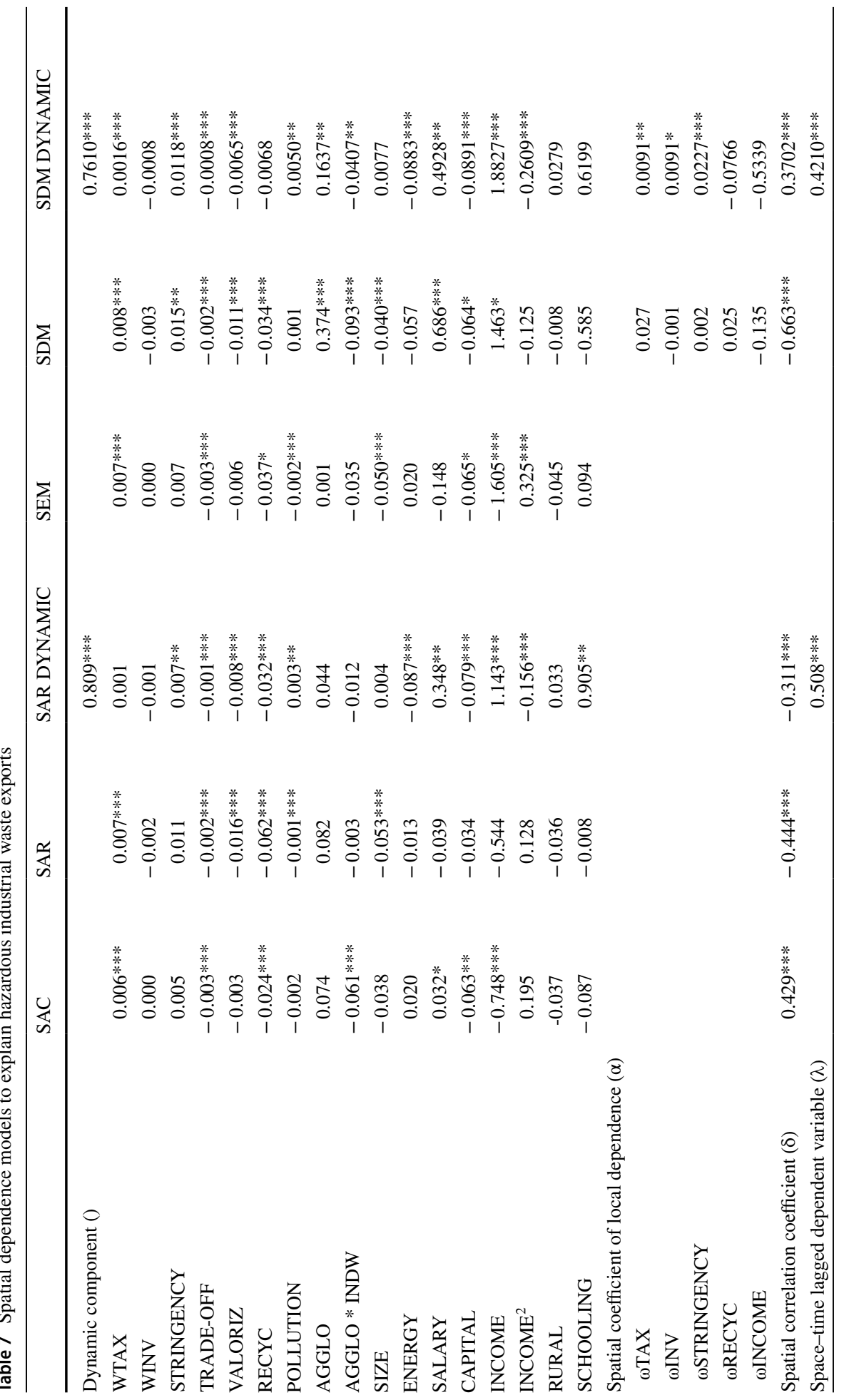




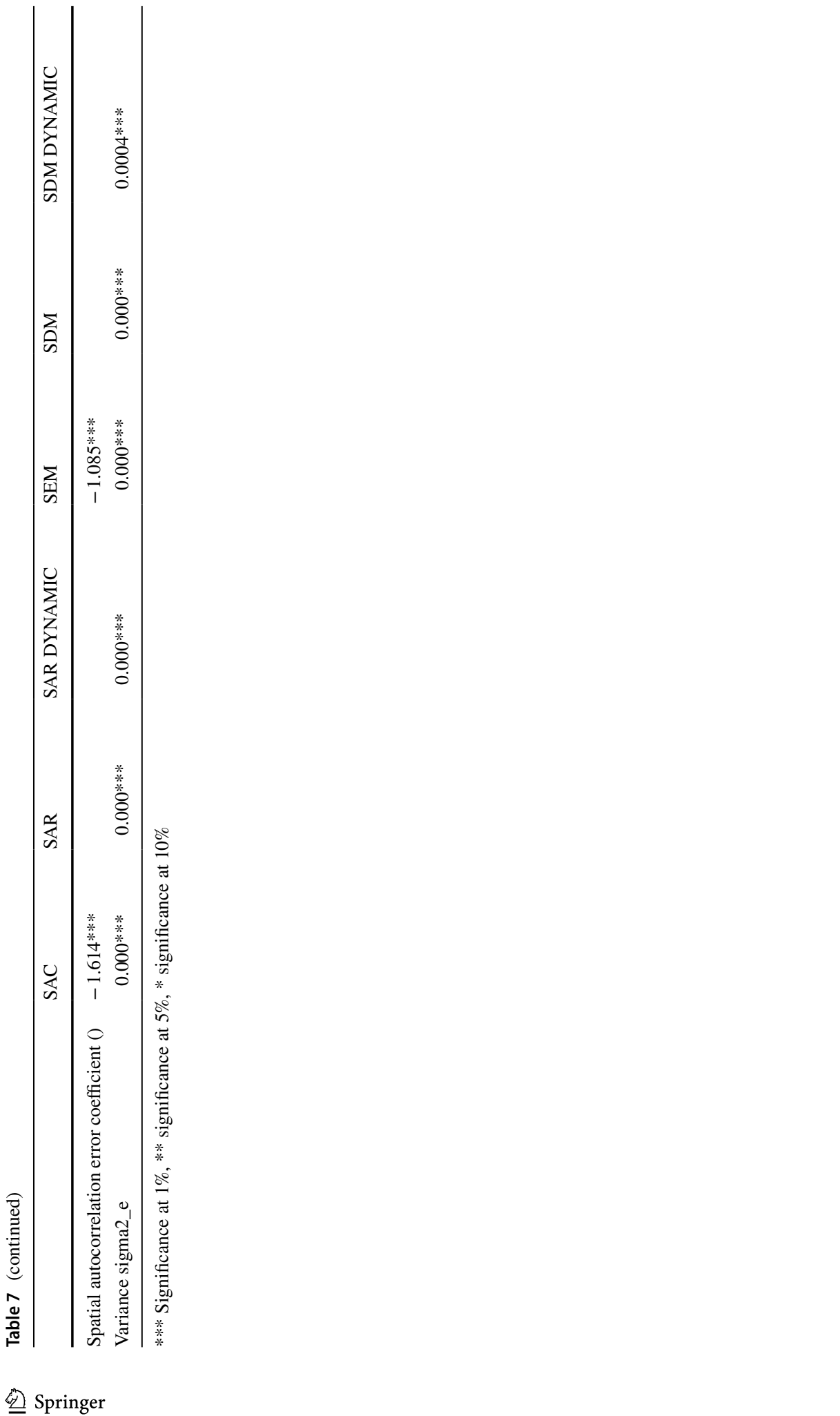


Table 8 LR test for model selection and LM test identifying spatial effects

\begin{tabular}{lcc}
\hline & \multicolumn{1}{l}{$\mathrm{X}^{2}$} & $p$-value \\
\hline Dynamic SAR versus SAR & 192.26 & 0.000 \\
Dynamic SDM versus SDM & 117.93 & 0.000 \\
Dynamic SDM versus dynamic SAR & 170.43 & 0.000 \\
Dynamic SDM versus SEM & 317.93 & 0.000 \\
LM error (error has no spatial autocorrelation) & 0.1317 & 0.7167 \\
LM lag (spatial lagged dependent variable has & 6.0711 & 0.0137 \\
$\quad$ no spatial autocorrelation) & & \\
\hline
\end{tabular}




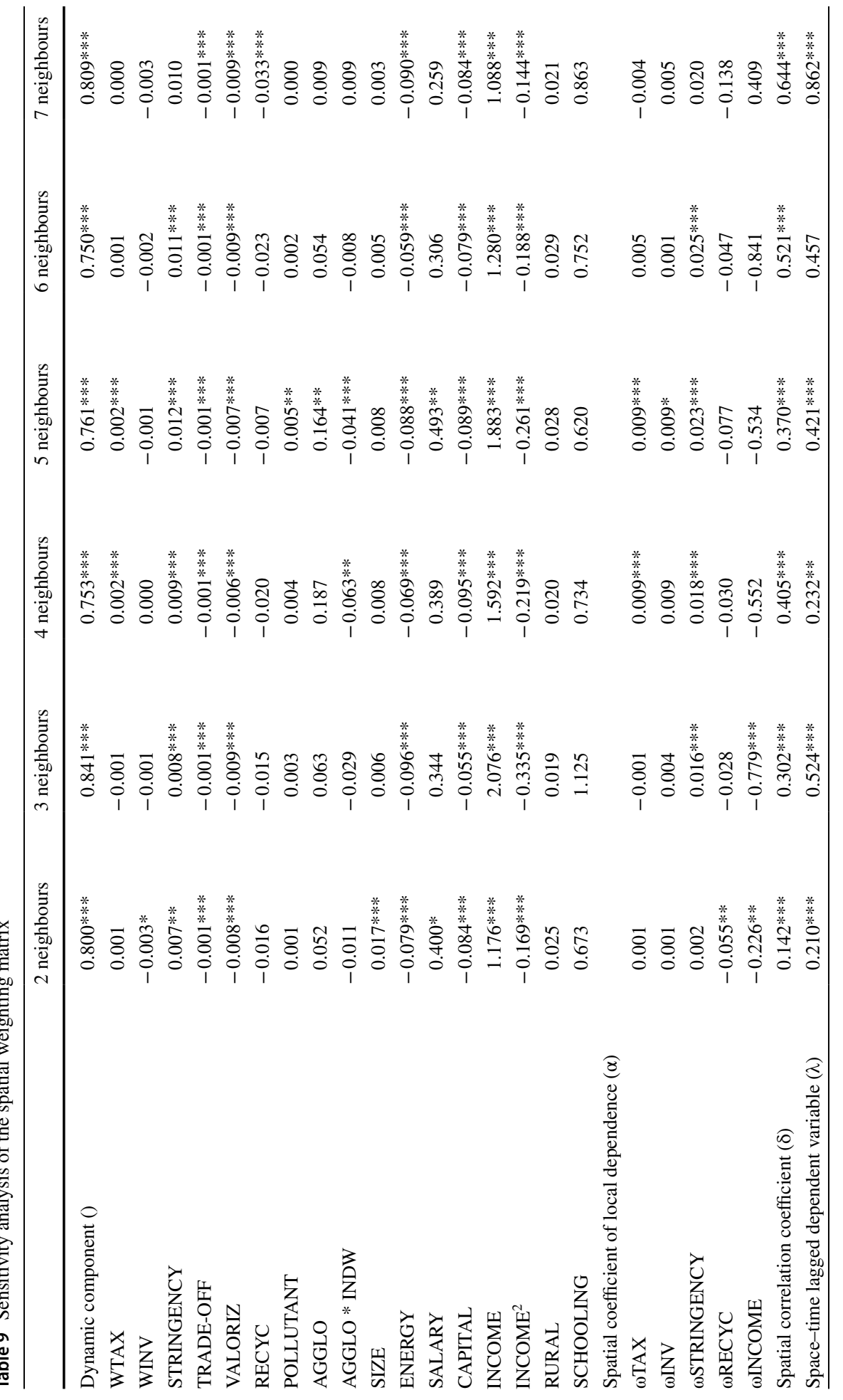




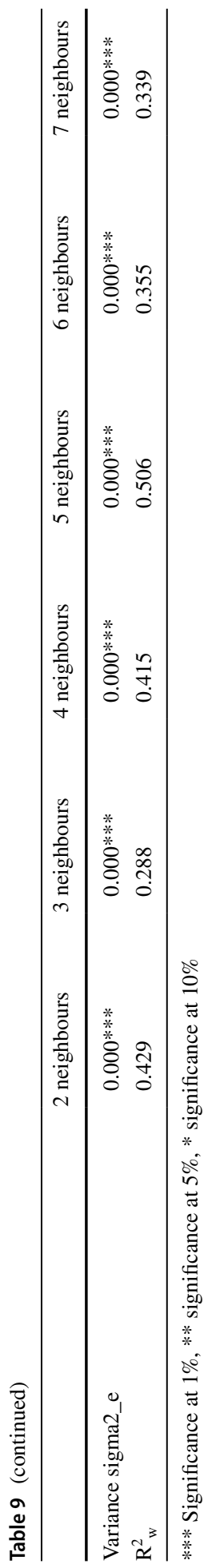


Acknowledgements The authors thank the Government of Aragon and FEDER (Public Economics Research Group), and the Project RTI2018-095799-B-I00 MCIU/AEI/FEDER, UE for their funding.

Funding Open Access funding provided thanks to the CRUE-CSIC agreement with Springer Nature.

Open Access This article is licensed under a Creative Commons Attribution 4.0 International License, which permits use, sharing, adaptation, distribution and reproduction in any medium or format, as long as you give appropriate credit to the original author(s) and the source, provide a link to the Creative Commons licence, and indicate if changes were made. The images or other third party material in this article are included in the article's Creative Commons licence, unless indicated otherwise in a credit line to the material. If material is not included in the article's Creative Commons licence and your intended use is not permitted by statutory regulation or exceeds the permitted use, you will need to obtain permission directly from the copyright holder. To view a copy of this licence, visit http://creativecommons.org/licenses/by/4.0/.

\section{References}

Alberini A, Bartholomew J (1999) The determinants of hazardous waste disposal choice: an empirical analysis of halogenated solvent waste shipments. Contemp Econ Policy 17(3):309-320

Amouzou E, Boudier F (2016) "European trade in hazardous waste: has EU waste policy succeeded or failed?", Erudite Working Paper 02, Erudite.

Anselin L (1988) Spatial econometrics: methods and models. Kluwer, Dordrecht

Baggs J (2009) International trade in hazardous waste. Rev Int Econ 17(1):1-16

Balsalobre-Lorente D, Gokmenoglu KK, Taspinar N, Cantos-Cantos JM (2019) An approach to the pollution haven and pollution halo hypotheses in MINT countries. Environ Sci Pollut Res 26:23010-23026

Basmann RL (1960) On finite sample distributions of generalized classical linear identifiability test statistics. J Am Stat Assoc 55(292):650-659

Belotti F, Hughes G, Piano Mortari A (2017) Spatial panel data models using Stata. Stand Genom Sci 17(1):139-180

Brülhart M, Mathys NA (2008) Sectoral agglomeration economies in a panel of European regions. Reg Sci Urban Econ 38(4):348-362

Brunel C, Levinson A (2016) Measuring the stringency of environmental regulations. Rev Environ Econ Policy 10(1):47-67

Bruyn S (1997) Explaining the environmental Kuznets curve: structural change and international agreements in reducing sulphur emissions. Environ Dev Econ 2:485-503

Çagatay S, Mihçi H (2003) Industrial pollution, environmental suffering and policy measures: an index of environmental sensitivity performance. JEAPM 5:205-245

Cole MA, Elliott RJR (2003) Determining the trade-environment composition effect: the role of capital, labor and environmental regulations. J Environ Econ Manag 46(3):363-383

Cole MA, Elliott RJR, Okubo T (2010) Trade, environmental regulations and industrial mobility: an industry-level study of Japan. Ecol Econ 69(10):1995-2002

D'Amato A, Massimiliano M, Nicolli F (2014) Illegal waste disposal, territorial enforcement and policy: evidence from regional data. SEEDS-Sustain Environ Econ Dyn Stud Work Pap 03:2014

de Bruyn SM, van den Bergh JCJM, Opschoor JB (1998) Economic growth and emissions: reconsidering the empirical basis of environmental Kuznets curves. Ecol Econ 25:161-175

Dinda S (2004) Environmental Kuznets curve hypothesis: a survey. Ecol Econ 49(1):431-455

Dinda S (2005) A theoretical basis for the environmental Kuznets curve. Ecol Econ 53:403-413

Dou J, Han X (2019) How does the industry mobility affect pollution industry transfer in China: empirical test on pollution haven hypothesis and porter hypothesis. J Clean Prod 217:105-115

Durbin J (1954) Errors in variables. Rev Int Stat Inst 22:23-32

Ekins P (1997) Kuznets curve for the environment and economic growth: examining the evidence. Environ Plan Ann 29:805-830

Elhorst J (2012) Dynamic spatial panels: models, methods, and inferences. J Geogr Syst 14(1):5-28

European Environment Agency (2012): "Movements of waste across the EU's internal and external borders”, EEA Report n. 7/2012, Copenhagen: https://doi.org/10.2800/62637.

Fikru MG (2012) Trans-boundary movement of hazardous waste: evidence from a new micro data in the European Union. Rev Eur Stud 4(1):3-14 
Fischer C, Junker H, Mazzanti M et al (2012) Transboundary shipments of waste in the european union reflections on data, environmental impacts and drivers. Eur Top Cent Sustain Consum Prod (ETC/ SCP) Copenhagen Denmark ETC/SCP Work Pap 2:2012

Glover JN (2017) A dirty dilemma: determinants of electronic waste importation, doctoral dissertation, international studies, Old Dominion University, https://doi.org/10.25777/k20n-nf48. https://digitalcom mons.odu.edu/gpis_etds/20

Grossman GM, Krueger AB (1995) Economic growth and the environment. Q J Econ 110:353-377

Hausman JA (1978) Specification tests in econometrics. Econometrica 46:1251-1271

Higashida K, Managi S (2014) Determinants of trade in recyclable wastes: evidence from commodity-based trade of waste and scrap. Environ Dev Econ 19(2):250-270

Hoechle D (2007) Robust Standard Errors for Panel Regressions with Cross-Sectional Dependence. Stand Genomic Sci 7(3):281-312

Hoyos R, Sarafidis V (2006) Testing for cross-sectional dependence in panel-data models. Stand Genom Sci 6(4):482-496

Jensen, C. D. (2012) The three W's of hazardous waste: Who, Why, and Where?, Doctoral dissertation. 3573 (https://researchrepository.wvu.edu/etd/3573).

Jensen, C. D. and S. McIntyre (2010): "What Causes Waste Flows? An Interregional Analysis of Welsh Waste Shipments", Regional Research Institute Publications and Working Papers, 47. https://resea rchrepository.wvu.edu/rri_pubs/47

Kellenberg D (2012) Trading wastes. J Environ Econ Manag 64(1):68-87

Kellenberg D (2015) The economics of the international trade of waste. Annu Rev Resour Econ 7:109-125

Kellenberg D, Levinson A (2014) Waste of effort? International environmental agreements. J Assoc Environ Resour Econ 1(1/2):135-169

Kunce M, Shogren JF (2005) On interjurisdictional competition and environmental federalism. J Environ Econ Manag 50:212-224

Leiter AM, Paolini A, Winner H (2011) Environmental regulation and investment: evidence from European industry data. Ecol Econ 70(4):759-770

Levinson A (1999a) NIMBY taxes matter: the case of state hazardous waste disposal taxes. J Public Econ $74: 31-51$

Levinson A (1999b) State taxes and interstate hazardous waste shipments. Am Econ Rev 89(3):666-677

Levinson A (2000) The missing pollution haven effect: examining some common explanations. Environ Resour Econ 15(3):343-364

Levinson A (2003) Environmental regulatory competition: a status report and Some new evidence. Natl Tax J 56(1):91-106

Mazzanti M, Montini A, Nicolli F (2012) Waste dynamics in economic and policy transitions: decoupling, convergence and spatial effects. J Environ Plan Manage 55(5):563-581

McConnell K (1997) Income and the demand for environmental quality. Environ Dev Econ 2:383-399

McGlinn L (2000) Spatial patterns of hazardous waste generation and management in the United States. Prof Geogr 52(1):11-22

Millimet D (2003) Assessing the empirical impact of environmental federalism. J Reg Sci 43(4):711-733

Mora and Dvorzhak (2016) Uso de vertederos de residuos industriales, Estratos, 116: 18-23. Available at https://www.researchgate.net/publication/320058028

Nuñez-Rocha T (2016) "Waste haven effect: unwrapping the impact of environmental regulation" Documents de travail du Centre d'Economie de la Sorbonne 16047, Université Panthéon-Sorbonne (Paris 1), Centre d'Economie de la Sorbonne

Özcan B, Öztürk I (2019) Environmental Kuznets curve: a manual. Academic Press, London, UK

Reams MA, Templet PH, Kemp GP (1993) Hazardous waste taxes in Louisiana and their effect on importation. Hazard Waste Hazard Mater 10(1):97-104

Rothman DS, de Bruyn SM (1998) Probing into the environmental Kuznets curve hypothesis. Ecol Econ 25:143-145

Sargan JD (1958) The estimation of economic relationships using instrumental variables. Econometrica 26:393-415

Sarkodie SA, Strezov V (2019) A review on environmental Kuznets curve hypothesis using bibliometric and meta-analysis. Sci Total Environ 649:128-145

Sasao T (2014a) Does industrial waste taxation contribute to reduction of landfilled waste? Dynamic panel analysis considering industrial waste category in Japan. Waste Manage 34:2239-2250

Sasao T (2014b) "Does industrial waste taxation contribute to waste reduction? Panel data analysis of the generation and final disposal of industrial waste in Japan". In Kreiser K, Lee S, Ueta K, Milne J and Ashiator H (eds.) Environmental Taxation and Green Fiscal Reform: Theory and Impact (Critical Issues in Environmental Taxation Series). Edward Elgar Publishing: pp 245-259 (Chapter 16). 
Sasao T (2014c) "Effects of local waste taxation and trade restrictions on industrial waste flow in Japan". In K. Asano and M. Takada (Eds.): Rural and Urban Sustainability Governance, United Nations University Press: pp 59-80 (Chapter 4).

Sasao T (2014d) "Industrial waste shipments and trade restrictions". In Kinnaman T and Takeuchi K (eds.): Handbook on Waste Management. Edward Elgar Publishing: pp 186-215 (Chapter 7).

Selden TM, Song D (1994) Environmental quality and development: is there a Kuznets curve for air pollution emissions? J Environ Econ Manag 27:147-162

Sigman H (1996) The effects of hazardous waste taxes on waste generation and disposal. J Environ Econ Manag 30(2):199-217

Stern DI, Common MS, Barbier EB (1996) Economic growth and environmental degradation: a critique of the environmental Kuznets curve. World Dev 24(7):1151-1160

Su Y, Yu Y (2019) Spatial association effect of regional pollution control. J Clean Prod 213:540-552

Wooldridge JM (2010) Econometric analysis of cross section and panel data, Chapter 13 Section 11, pp 502-517.

Wu D-M (1974) Alternative tests of independence between stochastic regressors and disturbances: finite sample results. Econometrica 42:529-546

Xiong L, de Jong M, Wang F, Cheng B, Chang Y (2018) Spatial spillover effects of environmental pollution in China's central plains urban agglomeration. Sustainability 10(4):994

Zhang K, Zhang Z, Liang Q (2017) An empirical analysis of the green paradox in China: from the perspective of fiscal decentralization. Energy Policy 103:203-211

Publisher's Note Springer Nature remains neutral with regard to jurisdictional claims in published maps and institutional affiliations. 